\title{
ANALISIS KESEDIAAN MEMBAYAR (WILLINGNESS TO PAY) BERAS CERDAS CV AN - NAHLAH DI KABUPATEN JEMBER
}

\author{
Anggraini Dwi Rahayu', Triana Dewi Hapsari², Julian Adam² \\ ${ }^{1}$ Mahasiswa Program Studi Agribisnis Fakultas Pertanian Universitas Jember \\ ${ }^{2}$ Staf Pengajar Program Studi Agribisnis Fakultas Pertanian Universitas Jember \\ email: Anggrainidwirahayu@gmail.com
}

\begin{abstract}
This study was aimed to identify : (1) consumer characteristic related to their willingness to pay for beras cerdas CV An - Nahlah in Jember ; (2) maximum average willingness to pay of beras cerdas CV An-Nahlah consumer in Jember ; (3) factors affecting consumer willingness to pay for beras cerdas CV An - Nahlah in Jember. The method used is analytical descriptive method. Sample taken purposively using incidental sampling technique. The data analyzed using descriptive analysis and multiple linier regression. The study showed that (1) the characteristics of beras cerdas $C V$ An - Nahlah consumer was related to their willingness to pay are; female, has a bachelor degree, include in adult group, married employed, average income Rp 1.500.000 - Rp 3.000.000 monthly their willingness to pay ranged between $R p 17.001$ - Rp 21.000 per 800 gram. (2) maximum average consumer willingness to pay is Rp 20.075 per 800 gram. (3) factors influenced consumer willingness to pay are; age, gender, married status, education, job, and monthly income.
\end{abstract}

Keywords: beras cerdas, willingness to pay

\section{PENDAHULUAN}

Beras merupakan bahan pangan pokok yang dikonsumsi oleh $90 \%$ penduduk Indonesia. Masyarakat Indonesia masih terbiasa mengkonsumsi beras sebagai bahan pangan utama meskipun ada beberapa jenis bahan makanan lokal yang tersedia. Berdasarkan kebijakan pembangunan pertanian 2015-2019 : (1) Kebijakan peningkatan ketahanan pangan (padi, jagung, kedelai, tebu, daging sapi, cabai dan bawang merah) yang berdampak bagi perekonomian, (2) Kebijakan pengembangan komoditas ekspor dan substitusi impor serta komoditas penyedia bahan baku bio-energi, (3) Kebijakan peningkatan daya saing produk pertanian melalui standarisasi produk dan proses, peningkatan rantai pasok, mutu dan keamanan pangan, (4) Kebijakan pengembangan infrastruktur (lahan, air, sarana dan prasarana) dan agroindustri di perdesaan, sebagai dasar atau landasan pengembangan bio-industri berkelanjutan. Salah satu kebijakan pembangunan pertanian pada tahun 2015 - 2019 adalah peningkatan daya saing produk pertanian melalui standarisasi produk dan proses, peningkatan rantai pasok, mutu dan keamanan pangan. Keamanan pangan menurut UU No. 18 Tahun 2012 keamanan pangan adalah kondisi dan upaya yang diperlukan untuk mencegah pangan dari kemungkinan cemaran biologis, kimia, dan benda lain yang dapat mengganggu, merugikan, dan membahayakan kesehatan manusia serta tidak bertentangan dengan agama, keyakinan, dan budaya masyarakat sehingga aman untuk dikonsumsi. Keamanan pangan diantaranya adalah menyediakan bahan pangan yang terbebas dari residu dan bahan kimia, juga pangan yang sehat dan bergizi bagi masyarakat.

Salah satu bentuk peningkatan daya saing produk pertanian yang memenuhi standarisasi keamanan pangan adalah dengan membuat inovasi beras cerdas berbahan dasar mocaf dan tepung jagung. Beras cerdas merupakan beras analog yang diciptakan oleh akademisi Universitas Jember, beras ini merupakan salah satu bentuk pengolahan singkong dikombinasikan dengan jagung yang menjadi produk berdaya saing dan aman dikonsumsi. Beras yang kita ketahui selama ini adalah beras konvensional yang berasal dari tanaman padi. Kini diciptakan beras cerdas yang terbuat dari bahan - bahan pangan selain beras konvensional namun dibentuk menyerupai beras konvensional agar tidak mengubah kebiasaan masyarakat dalam mengkonsumsi beras. Selain itu beras cerdas CV An 
- Nahlah memiliki kandungan IG yang rendah sehingga baik bagi penderita diabetes dan dilihat dari segi penyajian beras cerdas CV An - Nahlah lebih praktis karena dalam proses memasaknya tidak perlu dicuci terlebih dahulu. Dilihat dari segi kandungan manfaat dan diversifikasi pangan, beras cerdas CV An - Nahlah memiliki potensi konsumen yang cukup besar.

CV An - Nahlah adalah perusahaan yang bergerak dibidang pangan yang memproduksi beras cerdas dengan tujuan untuk menciptakan bahan pangan yang sehat dan bergizi bagi masyarakat. Harga yang ditetapkan adalah Rp 18.500 per kemasan dengan netto beras cerdas 800 gram apabila dikonversi dalam satu kilogram harganya menjadi Rp 23.000. Harga tersebut relatif mahal jika dibandingkan dengan harga beras konvensional yang rata - rata Rp 10.000 per kilogram, namun beras cerdas CV An - Nahlah memiliki kelebihan yaitu IG yang rendah dibandingkan beras konvensional sehingga baik bagi penderita diabetes. Sebagai produk baru yang diluncurkan pada tahun 2012, beras cerdas CV An - Nahlah sudah banyak mengalami pengembangan produk mulai dari perubahan komposisi bahan baku dan kemasan. Tujuan awal CV An - Nahlah adalah untuk mendukung program diversifikasi pangan dengan menciptakan beras cerdas sehingga konsumsi beras konvensional dapat berkurang, namun setelah beras diluncurkan dipasar pada tahun 2012 respon masyarakat terhadap beras cerdas CV An - Nahlah bukan untuk diversifikasi pangan tetapi dianggap sebagai beras kesehatan dan dibandingkan dengan beras - beras kesehatan yang lain seperti beras merah. Harga beras merah yang memiliki IG rendah dan manfaat sama dengan beras cerdas CV An - Nahlah adalah Rp 21.000 - Rp 23.000/kg.

Berdasarkan fenomena tersebut, peneliti ingin mengetahui berapa harga yang sesuai untuk beras cerdas CV An - Nahlah dilihat dari sisi konsumen sehingga peneliti melakukan penelitian analisis kesediaan membayar (willingness to pay). Adapun tujuan dari penelitian adalah: mengetahui karakteristik konsumen berkaitan dengan kesediaan membayar beras cerdas $\mathrm{CV}$ An - Nahlah di Kabupaten Jember, mengetahui nilai rata - rata kesediaan membayar maksimum konsumen beras cerdas CV An - Nahlah di Kabupaten Jember, mengetahui aktor - faktor yang mempengaruhi nilai kesediaan membayar beras cerdas CV An - Nahlah di Kabupaten Jember.

\section{METODE PENELITIAN}

Penentuan daerah penelitian dilakukan secara sengaja (purposive method). Dasar pertimbangan ditentukannya lokasi tersebut sebagai lokasi penelitian adalah karena CV An - Nahlah sebagai produsen beras cerdas berada di Kabupaten Jember. Persebaran konsumen beras cerdas yang dapat dideteksi oleh peneliti adalah di Kabupaten Jember sehingga peneliti menentukan Kabupaten Jember sebagai daerah penelitian. Metode penelitian yang digunakan adalah metode deskriptif dan metode analitis (Nazir, 2011). Metode deskriptif bertujuan untuk menguraikan atau mendeskripsikan suatu fenomena yaitu karakteristik konsumen beras cerdas CV An - Nahlah berkaitan dengan kesediaan membayar di Kabupaten Jember. Metode analistis digunakan untuk menganalisis kesediaan membayar konsumen dan faktor - faktor yang mempengaruhi nilai kesediaan membayar beras cerdas CV An - Nahlah di Kabupaten Jember.

Metode pengambilan sampel menggunakan non probability sampling. Teknik non probability sampling tidak memberikan peluang atau kesempatan yang sama bagi setiap unsur atau anggota populasi untuk dipilih menjadi smapel (Sumarmi dan Salamah, 2005). Konsumen beras cerdas di Kabupaten Jember masih terbatas sehingga untuk memudahkan proses penelitian, peneliti menggunakan teknik sampling insidental. Teknik sampling insidental adalah teknik pengambilan sampel berdasarkan kebetulan yaitu siapa saja yang secara kebetulan bertemu dengan peneliti dan dapat digunakan sebagai sampel (Sugiyono, 2008). Responden yang dipilih adalah yang pernah melakukan pembelian beras cerdas CV An - Nahlah di Kabupaten Jember dan berperan sebagai pengambil keputusan. Selain itu responden juga harus melewati tahap screening yaitu berusia lebih dari 16 tahun. Menurut Sumarwan (2015), responden yang berusia lebih dari 16 tahun memiliki pola pemikiran yang lebih matang dibandingkan dengan usia dibawahnya. Jumlah responden yang digunakan pada penelitian ini adalah 40 responden.

Karakteristik konsumen berkaitan dengan kesediaan membayar dianalisis dengan analisis deskriptif. Analisis deskriptif mendeskripsikan dan memberikan gambaran mengenai responden-responden dalam penelitian ini berdasarkan karakteristik demografi meliputi usia, jenis kelamin, status pernikahan, pendidikan terkahir, jenis pekerjaan, dan pendapatan perbulan. 
Selain itu juga dikaitkankan dengan kesediaan membayar beras cerdas CV An - Nahlah di Kabupaten Jember.

Analisis kesediaan membayar beras cerdas CV An - Nahlah dalam penelitian ini menggunakan pendekatan strategi penentuan harga. Pendekatan ini menggunakan survei langsung yaitu menanyakan secara langsung kepada responden mengenai berapa kesediaan membayarnya terhadap beras cerdas CV An - Nahlah dengan netto 800 gram. Prosedur dalam survei langsung strategi penentuan harga adalah (Foreit dan James, 2004) : (1) tahap awal mengetahui tujuan perusahaan dan siapa target segmentasi pasar, (2) mendesain kuisioner yang sesuai dengan kebutuhan peneliti, (3) menganalisis data dengan alat bantu microsoft excel 2007, (4) mengestimasi permintaan pada tingkat harga yang berbeda untuk mendapatkan harga yang tepat sehingga dapat memberikan rekomendasi kepada CV An - Nahlah.

Faktor - faktor yang mempengaruhi nilai kesediaan membayar dianalis menggunakan analisis regresi linier berganda dengan alat bantu SPSS. Analisis regresi linier berganda merupakan suatu teknik untuk melihat hubungan variabel dependen yang dipengaruhi oleh lebih dari satu variabel independen dalam suatu model matematis (Ghozali, 2009). Variabel dependen yang digunakan dalam penelitian ini adalah nilai WTP yang diberikan responden. Variabel independen yang diduga mempengaruhi nilai WTP responden adalah usia, jenis kelamin, status pernikahan, pendidikan terkahir, jenis pekerjaan, dan pendapatan perbulan. Adapun model analisis regresi linier berganda yang digunakan dalam penelitian ini adalah :

$\mathrm{Y}=\mathrm{a}_{0}+\mathrm{b}_{1} \mathrm{X}_{1}+\mathrm{b}_{2} \mathrm{D}_{1}+\mathrm{b}_{3} \mathrm{D}_{2}+\mathrm{b}_{4} \mathrm{X}_{4}+\mathrm{b}_{5} \mathrm{D}_{3}+$ $\mathrm{b}_{6} \mathrm{X}_{6}+\mathrm{e}$

Keterangan :

$\mathrm{Y}=$ Nilai WTP beras cerdas/800gram (rupiah)

$\mathrm{a}_{0}=$ Konstanta

$\mathrm{X}_{1}=\operatorname{Usia}(1=19-24 ; 2=25-35 ; 3=36-50 ; 4=51$ 65)

$\mathrm{D}_{1}=$ Dummy Jenis Kelamin $(0=$ Perempuan $; 1$ $=$ Laki-laki)

$\mathrm{D}_{2}=$ Dummy Status Pernikahan $(0=$ Menikah ; $1=$ Belum Menikah)

$\mathrm{X}_{4}=$ Pendidikan terakhir $(\mathrm{SMP}=1 ; \mathrm{SMA}=2$; $\mathrm{S} 1 / \mathrm{D} 3=3)$

$\mathrm{D}_{3}=$ Dummy Pekerjaan $(0=$ Pegawai $; 1=$ Non pegawai)
$\mathrm{X}_{6} \quad=$ Pendapatan per bulan

$(1=\mathrm{Rp}<1.500 .000 ; 2=\mathrm{Rp} 1.500 .000$ -

Rp3.000.000 ; 3=Rp >3.000.000)

Persamaan tersebut dianalisis menggunakan alat analisis SPSS 16. Analisis SPSS 16 digunakan untuk mengetahui pengaruh dari variabel independen (usia, jenis kelamin, status pernikahan, pendidikan terkahir, jenis pekerjaan, dan pendapatan perbulan) terhadap variabel dependen (nilai kesediaan membayar konsumen beras cerdas di Kabupaten Jember). Pengaruh ini secara statistik dapat diukur dari nilai koefisien determinasi, nilai statistik $f$, dan nilai statistik t. Uji statistik $f$ dilakukan untuk mengetahui apakah semua variabel independen yang dimasukkan kedalam model mempunyai pengaruh secara bersama - sama terhadap variabel dependen. Kriteria pengambilan keputusan:

a. f-hitung $>$ f-tabel $(\alpha=5 \%)$ maka H0 ditolak, berarti secara keseluruhan variabel independen berpengaruh secara nyata terhadap variabel dependen.

b. f-hitung $<$ f-tabel $(\alpha=5 \%)$ maka H0 diterima, berarti secara keseluruhan variabel independen tidak berpengaruh secara nyata terhadap variabel dependen.

Uji statistik t dilakukan untuk mengetahui sejauh mana pengaruh masing - masing variabel independen terhadap variabel dependen dengan menganggap variabel independen lainnya konstan. Kriteria pengambilan keputusan :

a. t-hitung $>$ t-tabel $(\alpha=5 \%)$ maka H0 ditolak, berarti variabel independen berpengaruh secara nyata terhadap variabel dependen.

b. t-hitung $<$ t-tabel $(\alpha=5 \%)$ maka H0 diterima, berarti variabel independen tidak berpengaruh secara nyata terhadap variabel dependen.

\section{HASIL DAN PEMBAHASAN}

Karakteristik Konsumen Beras Cerdas CV An - Nahlah di Kabupaten Jember Berkaitan Dengan Kesediaan Membayar (Willingness to pay). Karakteristik konsumen mengakibatkan adanya perbedaan dalam kebutuhan dan keinginan konsumen, tanpa memahami karakteristik yang melekat pada konsumen akan mengakibatkan ketidaktepatan para pelaku usaha dalam memproduksi, memasarkan, dan mejual produk-produknya (Nitisusastro, 2012).

1. Usia

Setiap konsumen akan memiliki kebutuhan yang berbeda sesuai dengan usianya (Sumarwan, 2015). Berdasarkan siklus hidupnya 
Tabel 1. Responden Berdasarkan Kelompok Usia Berkaitan dengan Kesediaan Membayar Pada Tahun 2016

\begin{tabular}{lccccccc}
\hline \multirow{2}{*}{ No } & Nilai WTP & \multicolumn{4}{c}{ Kelompok Usia } & \multicolumn{2}{c}{ Total } \\
\cline { 3 - 8 } & $\begin{array}{c}19-24 \text { th } \\
\text { (orang) }\end{array}$ & $\begin{array}{c}25-35 \text { th } \\
\text { (orang) }\end{array}$ & $\begin{array}{c}36-50 \text { th } \\
\text { (orang) }\end{array}$ & $\begin{array}{c}51-65 \text { th } \\
\text { (orang) }\end{array}$ & $\begin{array}{c}\text { Jumlah } \\
\text { (orang) }\end{array}$ & Persentase (\%) \\
\hline 1. & $13.000-17.000$ & 2 & 3 & 0 & 0 & 5 & 12,5 \\
2. & $17.001-21.000$ & 5 & 8 & 10 & 2 & 25 & 62,5 \\
3. & $21.001-25.000$ & 0 & 5 & 4 & 1 & 10 & 25 \\
\hline & Total & 7 & 16 & 14 & 3 & 40 & 100 \\
\hline
\end{tabular}

Sumber : Data Primer Tahun 2016

manusia dikelompokkan dalam 11 kelompok usia, namun dalam penelitian ini ternyata hanya ditemukan 4 kelompok usia. Kelompok usia tersebut adalah dewasa awal (19-24th), dewasa lanjut (25-35th), paruh baya (36-50th), dan tua (51-65th).

Pada tabel 1. diketahui bahwa responden kelompok usia dewasa awal (19-24 tahun) paling banyak bersedia membayar pada harga Rp17.001 - Rp21.000. Menurut Abdillah (2014), pada kelompok usia ini harga masih menjadi pertimbangan utama dibandingkan dengan manfaat kesehatan yang diperoleh, karena pada kelompok usia ini responden masih muda dan produktif. Responden pada usia ini membeli beras cerdas CV An - Nahlah sekedar coba - coba untuk dirasakan sendiri. Kelompok usia dewasa lanjut merupakan responden yang memiliki jumlah terbanyak dalam penelitian ini, jika dilihat terhadap kesediaan membayarnya ternyata responden pada kelompok usia dewasa lanjut paling banyak bersedia membayar pada harga Rp17.001 - Rp21.000 yakni sebanyak 8 orang yang memiliki kesediaan membayar pada rentang harga tersebut.
Kelompok usia paruh baya juga paling banyak bersedia membayar pada harga Rp17.001 - Rp21.000 yakni sebanyak 10 orang. Kelompok usia paruh baya sebagian besar membeli beras cerdas CV An - Nahlah untuk dikonsumsi dirinya sendiri, sehingga merasakan manfaat beras cerdas CV An - Nahlah secara langsung. Kelompok usia tua sebanyak 3 orang responden, dan 2 orang responden bersedia membayar pada harga Rp17.001 - Rp21.000 sedangkan 1 orang responden bersedia membayar pada harga Rp21.001 - Rp25.000. Pada kelompok usia tua, tidak ada responden yang memilih harga Rp13.000 - Rp17.000.

Responden pada penelitian ini membandingkan harga beras cerdas CV An - Nahlah dengan harga beras merah yang memiliki manfaat sama sehingga rentang harga yang paling banyak dipilih adalah Rp17.001 - Rp21.000 yakni dipilih oleh 25 orang dari seluruh kelompok usia yang ada dalam penelitian ini. Harga beras merah organik Rp21.000 - Rp23.000/kg sedangkan harga beras cerdas CV An - Nahlah Rp18.500/ 800 gram apabila dikonversi kedalam satu kilogram adalah Rp23.000 sehingga responden paling banyak memilih pada rentan harga tersebut.

Tabel 2. Responden Berdasarkan Jenis Kelamin Berkaitan dengan Kesediaan Membayar Pada Tahun 2016

\begin{tabular}{lccccc}
\hline \multirow{2}{*}{ No } & Nilai WTP & \multicolumn{2}{c}{ Jenis Kelamin } & \multicolumn{2}{c}{ Total } \\
\cline { 3 - 6 } & & $\begin{array}{c}\text { Perempuan } \\
\text { (orang) }\end{array}$ & $\begin{array}{c}\text { Laki - laki } \\
\text { (orang) }\end{array}$ & Jumlah (orang) & Persentase (\%) \\
\hline 1. & $13.000-17.000$ & 4 & 1 & 5 & 12,5 \\
2. & $17.001-21.000$ & 23 & 2 & 25 & 62,5 \\
3. & $21.001-25.000$ & 9 & 1 & 10 & 25 \\
\hline & Total & 36 & 4 & 40 & 100 \\
\hline
\end{tabular}

Sumber : Data Primer Tahun 2016 


\section{Jenis Kelamin}

Menurut Nitisusatro (2012), jenis kelamin membedakan setiap individu penduduk dengan jenis kelamin perempuan dan laki - laki. Hasil penelitian menunjukkan bahwa responden perempuan lebih banyak dibandingkan laki-laki. Perempuan sebanyak 36 orang dan laki-laki sebanyak 4 orang. Menurut Suwanda (2012), perempuan cenderung ingin coba-coba dan lebih konsumtif. Responden perempuan lebih banyak daripada laki-laki, hal ini dikarenakan beras cerdas CV An - Nahlah merupakan produk pangan yang menjadi kebutuhan rumah tangga. Kebanyakan kebutuhan rumah tangga dalam pengambilan keputusan dilakukan oleh perempuan sebagai ibu rumah tangga, sehingga tidak heran apabila perempuan mendominasi dalam melakukan pembelian beras cerdas CV An - Nahlah dibandingkan laki - laki.

Pada tabel 2. dapat diketahui bahwa responden perempuan paling banyak bersedia membayar pada harga Rp17.001 - Rp21.000 yakni sebanyak 23 orang, dan sebanyak 9 orang responden bersedia membayar pada harga Rp21.001 - Rp25.000. Hal ini disebabkan perempuan cenderung lebih cepat tertarik pada suatu produk berdasarkan kepercayaannya terhadap manfaat yang dimiliki produk tersebut. Selain itu, sebanyak 4 orang responden perempuan bersedia membayar pada harga $\mathrm{Rp} 13.000$ - Rp17.000, hal ini dikarenakan mereka memilih harga yang tidak terlalu jauh dengan harga beras konvensional (Rp10.000/kg).

Berdasarkan hasil penelitian diketahui bahwa responden laki - laki tidak terlalu memperdulikan harga karena laki - laki menyukai hal yang simpel dan tidak terlalu banyak pertimbangan dalam melakukan pembelian beras cerdas CV An - Nahlah. Hal ini dibuktikan dengan persebaran kesediaan membayar laki - laki hampir sama pada semua rentang harga.

\section{Status Pernikahan}

Status pernikahan, menurut Setiadi (2010) bahwa pada fase belum menikah seseorang lebih memprioritaskan sebagian pendapatannya untuk membeli peralatan dasar serta perabotan untuk tempat tinggal mereka, selain itu mereka lebih berorientasi pada rekreasi, makan diluar rumah, dan liburan, berbeda dengan yang sudah menikah biasanya secara finansial pendapatannya lebih baik daripada yang belum menikah apalagi tren saat ini istri juga sudah banyak yang bekerja.

Responden beras cerdas CV An - Nahlah di Kabupaten Jember sebagian besar memiliki status sudah menikah. Dari 40 responden dalam penelitian ini, sejumlah 37 orang berstatus sudah menikah dan 3 orang berstatus belum menikah. Berikut merupakan penjelasan responden berdasarkan status pernikahan berkaitan dengan kesediaan membayar (willingness to pay) beras cerdas CV An - Nahlah di Kabupaten Jember, lebih jelasnya dapat dilihat pada tabel 3 .

Pada tabel 3. dapat diketahui bahwa responden yang sudah menikah paling banyak bersedia membayar pada harga Rp17.001 Rp21.000 yakni sebanyak 23 orang, dan sebanyak 10 orang responden bersedia membayar pada harga Rp21.001 - Rp25.000. Responden dalam penelitian ini membandingkan harga dan manfaat beras cerdas CV An - Nahlah dengan beras merah, karena memiliki manfaat yang sama. Selain itu, sebanyak 4 orang responden sudah menikah bersedia membayar pada harga Rp13.000 - Rp17.000. Responden yang belum menikah sebanyak 3 orang. Berdasarkan hasil penelitian diketahui bahwa responden yang belum menikah mempertimbangkan harga sebagai pertimbangan utama dalam memutuskan untuk membeli sebuah produk, sehingga harga sangat penting dan tidak terlalu memperdulikan manfaat dari produk tersebut.

Tabel 3. Responden Berdasarkan Status Pernikahan Berkaitan dengan Kesediaan Membayar Pada Tahun 2016

\begin{tabular}{cccccc}
\hline \multirow{2}{*}{ No } & \multirow{2}{*}{ Nilai WTP } & \multicolumn{2}{c}{ Status Pernikahan } & \multicolumn{2}{c}{ Total } \\
\cline { 3 - 6 } & & Menikah (orang) & $\begin{array}{c}\text { Belum Menikah } \\
\text { (orang) }\end{array}$ & Jumlah (orang) & Persentase (\%) \\
\hline 1. & $13.000-17.000$ & 4 & 1 & 5 & 12,5 \\
2. & $17.001-21.000$ & 23 & 2 & 25 & 62,5 \\
3. & $21.001-25.000$ & 10 & 0 & 10 & 25 \\
\hline & Total & 37 & 3 & 40 & 100 \\
\hline
\end{tabular}

Sumber : Data Primer Tahun 2016 


\section{Pendidikan}

Pendidikan berpengaruh penting terhadap cara pandang dan sudut pandang seseorang, semakin tinggi tingkat pendidikan seseorang semakin baik cara berfikir dalam menghadapi suatu permasalahan atau keputusan dalam melakukan pembelian suatu barang (Sumarwan, 2015). Dalam penelitian ini diketahui bahwa dari 40 responden yang memiliki tingkat pendidikan terakhir S1/D3 sebanyak 23 orang, hal ini wajar karena semakin tinggi tingkat pendidikan seseorang kepeduliaannya terhadap bahan pangan yang sehat juga semakin meningkat. Tidak ada responden yang berpendidikan SD namun masih ada responden yang berpendidikan SMP.

Menurut Sumarwan (2015) konsumen dengan pendidikan yang lebih baik akan sangat responsif terhadap informasi, pendidikan, juga akan mempengaruhi dalam pilihan produk maupun merek. Hal ini akan memberikan peluang bagi CV An - Nahlah, semakin tinggi jenjang pendidikan konsumen akan memberikan asumsi yang baik terhadap cara pandang konsumen akan pentingnya mengkonsumsi produk sehat. Hal ini lebih jelasnya dapat dilihat pada tabel 4 .

Pada tabel 4. diketahui bahwa responden dengan pendidikan terakhir SMP sebanyak 3 orang dan semua bersedia membayar pada harga Rp13.000 - Rp17.000. Hal ini dikarenakan mereka adalah ibu rumah tangga dan pendapatan yang dimiliki adalah dari suaminya. Responden dengan pendidikan terakhir SMA sebanyak 14 orang, dan 12 orang responden bersedia membayar pada harga Rp17.001 - Rp21.000. Hal ini dikarenakan mereka membandingkan harga beras cerdas CV An - Nahlah dengan harga beras merah yang memiliki manfaat yang sama. Responden dengan pendidikan terakhir S1/D3 berjumlah 23 orang, dan paling banyak bersedia membayar pada harga Rp17.001 - Rp21.000 yakni sebanyak 13 orang.
Pada penelitian ini, ditemukan fakta bahwa ada responden dengan pendidikan terakhir sarjana yang bersedia membayar pada harga Rp13.000 - Rp17.000. Beliau mengaku bersedia membayar Rp18.500/800gram apabila sudah mengidap penyakit dan disarankan untuk mengkonsumsi beras yang lebih sehat. Selama beliau masih sehat, beliau lebih memilih mengkonsumsi beras konvensional karena harganya lebih murah. Beliau membeli beras cerdas CV An - Nahlah bukan untuk dikonsumsi sendiri, melainkan untuk ayahnya yang menderita diabetes dan pembelian yang beliau lakukan adalah pembelian yang pertama dan belum begitu percaya pada manfaat beras cerdas CV An - Nahlah.

\section{Pekerjaan}

Pekerjaan responden sebagian besar akan menentukan pendapatan, ketika pekerjaan sudah dalam status tetap biasanya pendapatannya juga akan tetap (Abdillah, 2014). Dari 40 responden diketahui bahwa jumlah responden memiliki status pekerjaan pegawai lebih banyak daripada non pegawai. Jumlah responden yang bekerja sebagai pegawai berjumlah 21 orang dan yang berstatus non pegawai sebanyak 19 orang. Hal ini dapat dilihat pada tabel 5 .

Pada tabel 5. dapat diketahui bahwa responden yang memiliki status pekerjaan pegawai sebanyak 21 orang dan non pegawai sebanyak 19 orang. Responden yang memiliki status pekerjaan pegawai tidak ada yang bersedia membayar pada harga Rp13000 - Rp17.000. Hal ini dikarenakan pegawai memiliki penghasilan yang tetap dan mandiri secara finansial sehingga tidak heran apabila kesediaan membayarnya juga tinggi.

Responden yang memiliki status pekerjaan non pegawai sebanyak 19 orang, dan paling banyak bersedia membayar pada harga Rp17.001 - Rp21.000. Responden yang memiliki status pekerjaan non pegawai sebagian besar adalah ibu tumah tangga, sehingga pendapatan

Tabel 4. Responden Berdasarkan Tingkat Pendidikan Berkaitan dengan Kesediaan Membayar Pada Tahun 2016

\begin{tabular}{|c|c|c|c|c|c|c|}
\hline \multirow{2}{*}{ No } & \multirow{2}{*}{ Nilai WTP } & \multicolumn{4}{|c|}{ Tingkat Pendidikan } & \multirow{2}{*}{$\begin{array}{c}\text { Total } \\
\text { Persentase (\%) }\end{array}$} \\
\hline & & SMP (orang) & SMA (orang) & $\mathrm{S} 1 / \mathrm{D} 3$ (orang) & Jumlah (orang) & \\
\hline 1. & $13.000-17.000$ & 3 & 1 & 1 & 5 & 12,5 \\
\hline 2. & $17.001-21.000$ & 0 & 12 & 13 & 25 & 62,5 \\
\hline 3. & $21.001-25.000$ & 0 & 1 & 9 & 10 & 25 \\
\hline & Total & 3 & 14 & 23 & 40 & 100 \\
\hline
\end{tabular}

Sumber : Data Primer Tahun 2016 
Tabel 5. Responden Berdasarkan Status Pekerjaan Berkaitan dengan Kesediaan Membayar Pada Tahun 2016

\begin{tabular}{|c|c|c|c|c|c|}
\hline \multirow{2}{*}{ No } & \multirow{2}{*}{ Nilai WTP } & \multicolumn{2}{|c|}{ Status Pekerjaan } & \multicolumn{2}{|c|}{ Total } \\
\hline & & Pegawai (orang) & Non Pegawai (orang) & Jumlah (orang) & Persentase (\%) \\
\hline 1. & $13.000-17.000$ & 0 & 5 & 5 & 12,5 \\
\hline 2. & $17.001-21.000$ & 12 & 13 & 25 & 62,5 \\
\hline 3. & $21.001-25.000$ & 9 & 1 & 10 & 25 \\
\hline & Total & 21 & 19 & 40 & 100 \\
\hline
\end{tabular}

Sumber : Data Primer Tahun 2016

mereka bergantung pada pendapatan suami. Diperlukan beberapa pertimbangan sebelum membeli suatu produk apakah produk tersebut bermanfaat bagi suami atau anggota keluarga yang lain. Hasil penelitian menunjukkan bahwa pembelian beras cerdas CV An - Nahlah dilakukan atas dasar kebutuhan anggota keluarga atau dirinya sendiri yang menderita penyakit diabetes.

\section{Pendapatan}

Pendapatan akan berpengaruh terhadap proses pengambilan keputusan dalam membeli sebuah barang, semakin rendah pendapatan seseorang barang yang dibeli hanyalah barang-barang yang menurutnya penting dengan kata lain mengesampingkan manfaat kesehatan dan lebih mempertimbangkan harga. Pendapatan yang diukur dari seorang konsumen biasanya bukan hanya pendapatan yang diterima oleh seorang individu, namun diukur dari pendapatan yang diterima oleh semua anggota keluarga konsumen (Sumarwan, 2015). Berikut merupakan penjelasan responden berdasarkan pendapatan berkaitan dengan kesediaan membayar (willingness to pay) beras cerdas CV An - Nahlah di Kabupaten Jember, lebih jelasnya dapat dilihat pada tabel 6 .
Berdasarkan tabel 6. diketahui bahwa responden yang memiliki pendapatan perbulan $<\mathrm{Rp} 1.500 .000$ sebanyak 11 orang, 4 orang bersedia membayar pada harga Rp13.000 Rp17.000, 7 orang bersedia membayar pada harga Rp17.001 - Rp21.000. Hal ini dikarenakan pada pendapatan tersebut mayoritas responden sebagai ibu rumah tangga yang suaminya tidak memiliki penghasilan tetap sehingga dia bertindak rasional atau menyesuaikan dengan pendapatan.

Responden yang memiliki pendapatan Rp 1.500.000 - Rp 3.000.000 memiliki jumlah terbanyak yaitu 23 orang, 1 orang bersedia membayar pada harga Rp13.000 - Rp17.000, 18 orang bersedia membayar pada harga Rp17.001 - Rp21.000, dan 4 orang bersedia membayar pada harga Rp21.001 - Rp25.000. Secara logika pendapatan responden $\mathrm{Rp} 1.500 .000-\mathrm{Rp}$ 3.000.000 perbulan sudah mendekati dan lebih tinggi dibandingkan UMK Kabupaten Jember yang sebesar Rp 1.629.000 sehingga kemampuan daya belinya untuk membeli beras cerdas CV An - Nahlah sudah mampu dibandingkan dengan responden yang memiliki pendapatan $<$ Rp 1.500.000 perbulan.

Berbeda dengan responden yang memiliki pendapatan $>$ Rp 3.000.000, mereka berjumlah 6 orang dan semuanya bersedia membayar pada harga Rp21.001 - Rp25.000. Hal ini karena

Tabel 6. Responden Berdasarkan Pendapatan Berkaitan dengan Kesediaan Membayar Pada Tahun 2016

\begin{tabular}{|c|c|c|c|c|c|c|}
\hline \multirow{2}{*}{ No } & \multirow{2}{*}{ Nilai WTP } & \multicolumn{3}{|c|}{ Pendapatan Perbulan } & \multicolumn{2}{|r|}{ Total } \\
\hline & & $<1,5 \mathrm{jt}$ (orang) & $1,5-3 \mathrm{jt}$ (orang) & $>3 \mathrm{jt}$ (orang) & Jumlah (orang) & Persentase (\%) \\
\hline 1. & $13.000-17.000$ & 4 & 1 & 0 & 5 & 12,5 \\
\hline 2. & $17.001-21.000$ & 7 & 18 & 0 & 25 & 62,5 \\
\hline 3. & $21.001-25.000$ & 0 & 4 & 6 & 10 & 25 \\
\hline & Total & 11 & 23 & 6 & 40 & 100 \\
\hline
\end{tabular}


ga kesediaan responden untuk membayar beras cerdas CV An - Nahlah juga tinggi. Pendapatan yang tinggi menyebabkan responden mengesampingkan harga dan lebih mementingkan manfaat kesehatan yang diperoleh dari mengonsumsi beras cerdas CV An - Nahlah.

\section{Analisis Kesediaan Membayar (Willingness to pay) Beras Cerdas CV An - Nahlah di Ka- bupaten Jember}

Berdasarkan hasil survei yang dilakukan terhadap 40 responden dalam penelitian ini, diketahui bahwa sebanyak 35 responden bersedia membayar beras cerdas CV An - Nahlah dengan harga lebih dari Rp 18.500/800gram (dapat dilihat pada tabel7). Responden - responden tersebut bersedia membayar di atas harga yang ditawarkan karena memiliki keyakinan bahwa beras cerdas CV An - Nahlah memberikan banyak manfaat dibanding beras konvensional. Sebanyak 5 responden bersedia membayar beras cerdas CV An - Nahlah dengan harga lebih rendah dari Rp18.500,00/800gram (dapat dilihat pada tabel 7). Kondisi ini dikarenakan responden-responden tersebut memiliki keterbatasan pendapatan sehingga mereka bertindak rasional (menyesuaikan dengan pendapatan). Selain itu, ada responden juga tidak begitu yakin dengan manfaat beras cerdas CV An - Nahlah sehingga memilih harga yang lebih murah.

Pada penelitian ini ditemukan fakta bahwa sebagian besar responden tidak membandingkannya dengan beras konvensional karena harganya jauh lebih mahal. Responden melihat dari segi kandungan manfaat yang dimiliki beras cerdas CV An - Nahlah, sehingga lebih condong membandingkannya dengan beras merah karena memiliki manfaat yang sama. Kandungan indeks glikemik beras cerdas CV An - Nahlah lebih rendah dibandingkan beras konvensional, sehingga memiliki manfaat yang baik untuk diabetes. Kesamaan manfaat ini membuat responden berfikir bahwa beras cerdas CV An - Nahlah bisa disamakan dengan beras merah bukan beras konvensional karena ada kelebihan manfaat yang diberikan. Harga yang diberikan juga dibandingkan dengan harga beras merah dan hasilnya menurut responden tidak begitu mahal.

Sebagai produk baru dan belum lama beredar dipasar, permasalahan harga masih menjadi permasalahan utama dalam hal ini sehingga diperlukan strategi penentuan harga yang tepat. CV An - Nahlah sebagai satu - satunya produs- en beras cerdas di Kabupaten Jember memiliki pasar monopoli dalam memasarkan produknya. Dalam pasar monopoli CV An - Nahlah berlaku sebagai price maker (penentu harga), selain itu keseluruhan kurva permintaan adalah milik CV An - Nahlah sehingga posisi ini harus bisa dimanfaatkan maksimal oleh CV An - Nahlah agar bisa mendapatkan keuntungan yang maksimal. Dalam pasar monopoli, harga yang ditetapkan cenderung lebih tinggi sehingga ada konsumen yang tidak dapat menjangkau atau dikenal dengan istilah deadweight loss. Hasil penelitian menunjukkan ada lima orang responden yang berada dalam posisi tidak dapat menjangkau dikarenakan tingginya harga. Nilai kesediaan membayar terendah dalam penelitian ini adalah Rp 13.000,00 per 800 gram beras cerdas CV An - Nahlah dan nilai kesediaan membayar tertinggi adalah Rp 25.000,00 per 800 gram beras cerdas CV An - Nahlah. Distribusi nilai (harga) yang bersedia dibayarkan 40 responden dalam penelitian ini terhadap 800 gram beras cerdas CV An Nahlah lebih jelasnya dapat dilihat pada tabel 7 .

Berdasarkan tabel 7. dapat diketahui sebaran nilai yang bersedia dibayarkan oleh responden beserta jumlah responden yang memilih nilai tersebut. Nilai WTP yang paling banyak dipilih oleh responden dalam penelitian ini adalah Rp 20.000,00. Nilai rata-rata WTP responden adalah sebesar Rp. 20.075,00 per 800 gram, padahal harga yang ada dipasar pada saat penelitian adalah Rp 18.500. Nilai rata - rata hasil penelitian sebesar Rp 20.075 ini menunjukkan adanya kelebihan harga yang bersedia dibayarkan oleh responden sebesar Rp 1.575. Kelebihan harga sebesar Rp 1.575 ini dalam istilah ekonomi disebut surplus konsumen. Surplus konsumen adalah kelebihan harga yang bersedia dibayarkan oleh konsumen diatas harga keseimbangan. Tinggi rendahnya nilai suatu barang tergantung pada konsumen yang memberikan penilaian, jadi suatu barang baru mempunyai arti bagi seorang konsumen apabila barang tersebut mempunyai tambahan kepuasan yang tinggi sehingga konsumen bersedia membayar dengan harga yang tinggi pula (Hariyati, 2007). Responden dalam penelitian ini sebagian besar membandingkan harga beras cerdas CV An - Nahlah dengan harga beras merah yang memiliki manfaat sama yakni baik untuk penyakit diabetes. Harga beras merah organik \pm Rp. $21.000 / \mathrm{kg}-\mathrm{Rp} 23.000 / \mathrm{kg}$ 
Tabel 7. Nilai WTP, Jumlah Responden, dan Frekuensi Kumulatif Responden Beras Cerdas CV An - Nahlah Pada Tahun 2016

\begin{tabular}{ccrrr}
\hline Nilai WTP (rupiah) & $\begin{array}{c}\text { Jumlah Responden } \\
\text { (orang) }\end{array}$ & $\begin{array}{c}\text { WTP } \\
\text { (rupiah) }\end{array}$ & Persentase (\%) & $\begin{array}{c}\text { Persentase Kumulatif } \\
(\%)\end{array}$ \\
\hline$(1)$ & $(2)$ & $(3=1 \times 2)$ & $\left(4=2 / \sum 2\right)$ & $(5)$ \\
13.000 & 1 & 13.000 & 2,5 & 2,5 \\
15.000 & 4 & 60.000 & 10,0 & 12,5 \\
19.000 & 5 & 95.000 & 12,5 & 25,0 \\
$\mathbf{2 0 . 0 0 0}$ & $\mathbf{1 3}$ & $\mathbf{2 6 0 . 0 0 0}$ & $\mathbf{3 2 , 5}$ & $\mathbf{5 7 , 5}$ \\
21.000 & 7 & 147.000 & 17,5 & 75,0 \\
22.000 & 7 & 154.000 & 17,5 & 92,5 \\
24.000 & 1 & 24.000 & 2,5 & 95,0 \\
25.000 & 2 & 50.000 & 5,0 & 100,0 \\
Total & 40 & 803.000 & 100 & 100,0 \\
\hline Rata-rata nilai WTP $\left(\sum 3 / \sum 2\right)$ & 20.075 & & \\
Harga yang berlaku di Pasar & 18.500 & & \\
\hline
\end{tabular}

Sumber : Data Primer, Tahun 2016

sehingga harga beras cerdas CV An - Nahlah dianggap tidak terlalu mahal. Harga beras cerdas CV An - Nahlah adalah Rp 18.500/800 gram apabila dikonversi kedalam satu kilogram harganya menjadi Rp 23.000, sehingga dapat bersaing dengan beras merah organik. Selanjutnya membuat kurva permintaan beras cerdas $\mathrm{CV}$ An - Nahlah berdasarkan data nilai kesediaan membayar, jumlah responden yang memilih nilai WTP tertentu, dan frekuensi kumulatif responden. Hal ini dapat dilihat lebih jelas pada table 8 .

Berdasarkan tabel 8. diketahui nilai WTP dan jumlah responden yang memilih nilai WTP tertentu. Kurva pemintaan dibentuk menggunakan hubungan nilai WTP yang dipilih oleh responden dengan frekuensi kumulatif dari jumlah individu yang memilih suatu nilai WTP tertentu.
Asumsinya adalah individu yang bersedia membayar suatu nilai tertentu (tinggi) sudah pasti bersedia membayar nilai WTP yang berada dibawahnya. Hal ini lebih jelasnya dapat dilihat pada gambar 1.

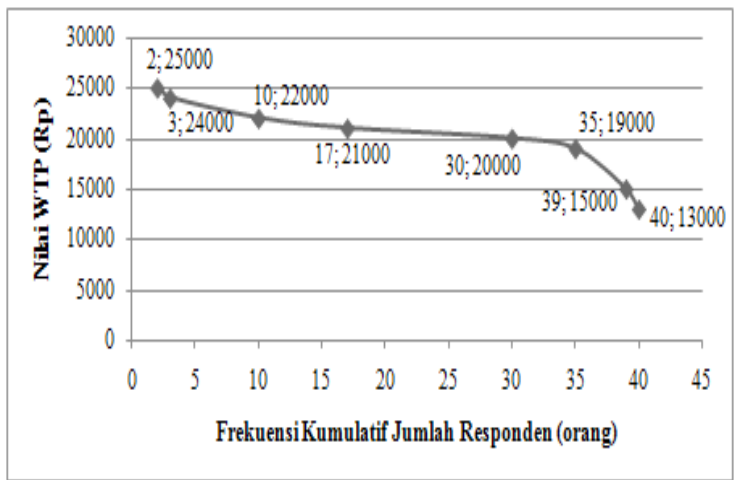

Gambar 1. Kurva Permintaan

Tabel 8. Nilai WTP, Jumlah Responden, dan Frekuensi Kumulatif Responden Beras Cerdas CV An - Nahlah Pada Tahun 2016

\begin{tabular}{ccc}
\hline Nilai WTP (rupiah) & Jumlah Responden (orang) & Frekuensi Kumulatif Reponden (orang) \\
\hline 25000 & 2 & 2 \\
24000 & 1 & 3 \\
22000 & 7 & 10 \\
21000 & 7 & 17 \\
20000 & 13 & 30 \\
19000 & 5 & 35 \\
15000 & 4 & 39 \\
13000 & 1 & 40 \\
\hline
\end{tabular}

Sumber : Data Primer, Tahun 2016 
Berdasarkan gambar 1. dapat dilihat bahwa semakin tinggi tingkat WTP, lebih sedikit jumlah responden yang bersedia untuk membayar beras cerdas CV An - Nahlah. Hal ini memberikan penjelasan bahwa kemampuan membeli responden semakin sedikit apabila harganya semakin tinggi. Perlu diingat bahwa pasar beras cerdas CV An - Nahlah ini adalah pasar monopoli, dalam pasar monopoli harga yang berlaku sangat berpengaruh terhadap permintaan konsumen terhadap suatu barang. Kenaikan harga beras cerdas CV An - Nahlah akan menurunkan permintaan, karena dalam pasar monopoli produsen berwenang sebagai penentu harga. Dalam pasar monopoli, harga yang ditetapkan sudah membuat produsen mendapatkan keuntungan namun belum bisa mendapatkan keuntungan yang maksimum. Kondisi ini dikarenakan ada potensi pasar yang hilang. Potensi pasar ini seharusnya bisa diambil keuntungannya oleh perusahaan atau dikenal dengan istilah deadweight loss. Produsen atau perusahaan bisa mendapatkan keuntungan yang maksimum apabila potensi pasar yang hilang ini dimaksimalkan.

Dalam penelitian ini ditemukan 5 pembeli potensial yang berada dalam wilayah deadweight loss, artinya mereka berkeinginan untuk membeli beras cerdas namun tidak terjangkau karena tingginya harga. Kondisi ini merupakan peluang perusahaan untuk mendapatkan keuntungan yang maksimum, dengan cara mengembangkan produk dan memperbesar volume penjualan. $\mathrm{CV}$ An - Nahlah perlu melakukan segmentasi pasar berdasarkan kemampuan konsumen untuk membeli.

Pada tabel 7. diketahui bahwa hasil penelitian menunjukkan bahwa harga rata - rata kesediaan membayaar adalah Rp 20.075. Pada harga $\mathrm{Rp} 20.000$ kebawah maka jumlah konsumen yang meminta beras cerdas sebesar $57,5 \%$, artinya jika perusahaan menetapkan harga sebesar Rp 20.075 maka hanya konsumen yang bersedia membeli dengan harga Rp 20.000 keatas yang mau membelinya dan itu sebesar $42,5 \%$. Pada harga Rp 18.500 kebawah maka jumlah konsumen yang meminta beras cerdas CV An - Nahlah sebesar 12,5\% yang berarti jika CV An - Nahlah menentukan harga Rp 18.500 maka hanya konsumen yang bersedia membeli dengan harga $\mathrm{Rp}$ 18.500 keataslah yang akan membelinya dan itu sebesar $87,5 \%$, sehingga dapat dikatakan terdapat perbedaan kemampuan untuk membeli.
CV An - Nahlah pada proses produksi selanjutnya akan menaikkan harga dari $\mathrm{Rp}$ 18.500/800gram menjadi Rp 20.000/800gram. Kenaikan harga ini dikarenakan adanya pergantian kemasan dari plastik menjadi karton, tujuan utama pergantian kemasan ini adalah untuk mempercantik kemasan beras cerdas $\mathrm{CV}$ An - Nahlah agar terlihat lebih menarik. Pergantian kemasan ini diharapkan dapat meningkatkan keuntungan perusahaan. Pada saat ini CV An - Nahlah masih menguasai konsumen yang memiliki kemampuan membayar yang tinggi sedangkan potensi pasar yang hilang adalah konsumen yang memiliki kemampuan membayar yang rendah. Hasil penelitian menunjukkan konsumen yang bersedia membayar dibawah harga rata - rata hasil penelitian sebesar 57,5\%. Populasi ini seharusnya bisa dijadikan target segmentasi pasar oleh CV An - Nahlah agar tetap bisa berperilaku monopoli pada segmen pasar yang berbeda dengan melakukan diversifikasi produk, sehingga keuntungan yang diperoleh bisa maksimum.

CV An - Nahlah sebaiknya melakukan diversifikasi produk, produk yang diproduksi pada saat ini berkualitas baik menggunakan bahan - bahan berkualitas tinggi dikemas dengan kemasan karton untuk konsumen dengan kemampuan membayar tinggi. Selain itu CV An - Nahlah juga perlu menciptakan produk dengan kualitas biasa (kualitasnya diturunkan) dengan menggunakan bahan - bahan yang juga berkualitas biasa sehingga harga jualnya bisa lebih rendah dari beras cerdas CV An - Nahlah yang berkualitas tinggi. Beras cerdas dengan kualitas biasa adalah beras cerdas yang memiliki bentuk yang sama dengan beras cerdas berkualitas tinggi, namun bahan - bahan yang digunakan dalam proses pembuatan kualitasnya diturunkan sehingga biaya produksinya lebih rendah. Selain bahan - bahan, produk beras cerdas CV An - Nahlah yang untuk konsumen dengan kemampuan membayar yang rendah bisa dikemas dengan kemasan plastik agar menghemat biaya produksi. Dengan bertindak demikian, CV An - Nahlah masih dapat berperilaku monopoli dengan dua produk yang memiliki segmentasi pasar yang berbeda. Beras cerdas CV An - Nahlah yang memiliki kualitas biasa dikemas dengan kemasan plastik dan harganya tidak jauh dengan harga beras konvensional seperti Rp 15.000/800gram sedangkan beras cerdas CV An - Nahlah yang memiliki kualitas tinggi dike- 
mas dengan kemasan karton dengan harga $\mathrm{Rp}$ 20.000/800 gram seperti yang akan ditetapkan oleh CV An - Nahlah. Dengan dua produk ini, diharapkan CV An - Nahlah bisa mendapatkan keuntungan yang maksimum karena tidak ada potensi pasar yang hilang atau dikenal dengan istilah deadweight loss.

Faktor - faktor Yang Mempengaruhi Kesediaan Membayar Responden (Willingness to pay) Beras Cerdas CV An - Nahlah di Kabupaten Jember

Faktor-faktor yang diduga mempengaruhi responden dalam menentukan nilai WTP dianalisis menggunakan analisis regresi linier berganda. Regresi linier berganda dipilih karena memudahkan peneliti mengetahui seberapa besar pengaruh variabel - variabel independen yang digunakan dalam penelitian ini terhadap variabel dependen yang diuji secara bersamaan. Taraf nyata yang digunakan dalam menguji signifikansi adalah $\alpha=5 \%$, artinya tingkat kepercayaan hasil penelitian ini sebesar 95\%. Sebelum mengintepretasi hasil output dari SPSS, perlu dilakukan pengujian asumsi klasik regresi untuk melihat kevalidan regresi dalam memprediksi hasil. Penggunaan asumsi ini merupakan konsekuensi dari penggunaan Ordinary Least Square (OLS) dalam menghitung persamaan regresi. Asumsi ini dilakukan dengan beberapa pengujian yaitu: (1) uji normalitas, (2) uji multikolinieritas, (3) uji heteroskedastisitas, dan (4) uji autokorelasi.

\section{Uji Normalitas}

Pengujian normalitas dilakukan untuk melihat kenormalan distribusi data, salah satu caranya adalah dengan melihat grafik. Grafik histogram dari hasil output SPSS sudah terdistribusi dengan normal. Hal ini dibuktikan bahwa bentuk data dalam grafik yang terdistribusi normal akan mengikuti pola konsumsi normal pula dimana bentuk grafiknya mengikuti bentuk lonceng. Pada grafik PP plots data tersebar dengan normal, dibuktikan dengan nilai PP plots yang tidak menyimpang dari garis diagonal.

\section{Uji Multikolinieritas}

Asumsi multikolinearitas menyatakan bahwa variabel independen harus terbebas dari gejala multikolineritas. Gejala multikolinieritas adalah gejala korelasi antar variabel independen, gejala ini ditunjukkan dengan korelasi yang signifikan antar variabel independen. Untuk me- lihat gejala multikolinieritas dapat dilihat pada hasil collinierity statistics kolom VIF pada tabel 9.

Tabel 9. Hubungan variabel independen dan Nilai VIF

\begin{tabular}{lc}
\hline \multicolumn{1}{c}{ Variabel } & VIF \\
\hline Usia & 1.288 \\
Jenis Kelamin & 1.239 \\
Status Pernikahan & 1.220 \\
Pendidikan Terakhir & 2.141 \\
Pekerjaan & 1.988 \\
Pendapatan & 1.527 \\
\hline
\end{tabular}

Sumber : Data Primer Tahun 2016

Hasil VIF yang mendekati satu menunjukkan tidak adanya gejala multikolinieritas, sedangkan VIF yang bernilai di atas 10 menunjukkan adanya gejala multikolinieritas. Hasil output SPSS pada tabel 5.12, tidak satupun variabel yang memiliki nilai VIF di atas 10 . Nilai pada semua variabel lebih kecil dari 10 , sehingga model tidak menunjukkan adanya gejala multikolinieritas.

\section{Uji Heterokedesitas}

Uji heterokedastisitas adalah asumsi dalam regresi di mana varians dari residual tidak sama untuk satu pengamatan ke pengamatan yang lain. Pengujian ini dapat dilakukan dengan menggunakan scatterplot yang menggunakan alat bantu software SPSS. Pada scatterlplot dapat dilihat bahwa terdapat pola yang tidak sama antar satu varians dari residual. Sehingga dapat diambil kesimpulan bahwa persamaan regresi memenuhi asumsi heterokedastisitas.

\section{Uji Autokorelasi}

Salah satu cara untuk mengetahui adanya autokorelasi adalah dengan mengetahui nilai durbin watson. Uji durbin watson digunakan untuk autokorelasi tingkat satu dan mensyaratkan adanya konstanta dalam model regresi tidak ada variabel lag diantara variabel independen. Nilai durbin watson adalah 2,012 dan nilai dU tabel adalah 1,8538 sehingga $\mathrm{d}>\mathrm{dU}$ dan $\mathrm{d}<4-\mathrm{dU}$. Nilai 2,012 $>1,8538$ dan 2,012 $<2,1462$ sehingga dapat disimpulkan bahwa tidak ada gejala autokorelasi.

Setelah persamaan memenuhi uji asumsi klasik dan model yang digunakan sudah BLUE, maka dapat dilanjutkan analisis selanjutnya. Analisis regresi linier berganda digunakan unT 
Tabel 10. Hasil Analisis Regresi Linier Berganda Pada Faktor - faktor yang Mempengaruhi Kesediaan Membayar Beras Cerdas CV An - Nahlah

\begin{tabular}{llll}
\hline \multicolumn{1}{c}{ Variabel } & \multicolumn{1}{c}{ Koef. Regresi } & \multicolumn{1}{c}{ t hitung } & \multicolumn{1}{c}{ Sig. } \\
\hline Konstanta & 9338,543 & 6,487 & 0,000 \\
Usia $\left(\mathrm{X}_{1}\right)$ & 675,400 & 2,049 & $0,048^{*}$ \\
Jenis Kelamin $\left(\mathrm{D}_{1}\right)$ & $-2257,257$ & $-2,470$ & $0,019^{*}$ \\
St.Pernikahan $\left(\mathrm{D}_{2}\right)$ & $-42,450$ & $-0,041$ & 0,967 \\
Pendidikan $\left(\mathrm{X}_{4}\right)$ & 3008,846 & 5,279 & $0,102 \mathrm{E}^{-6 *}$ \\
Pekerjaan $\left(\mathrm{D}_{3}\right)$ & $-1541,862$ & $-2,217$ & $0,034^{*}$ \\
Pendapatan $\left(\mathrm{X}_{6}\right)$ & 1336,067 & 2,768 & $0,009^{*}$ \\
\hline Durbin Watson & 2,012 & & \\
F-hitung & 11,992 & F-tabel & 2,34 \\
t-tabel $(\alpha=0.05)$ & 2,03224 & & \\
Adj. R Square & 0,628 & & \\
Sumb : Data Prim & & &
\end{tabular}

Sumber : Data Primer Tahun 2016

tuk mengetahui faktor - faktor yang mempengaruhi kesediaan membayar responden beras cerdas CV An -Nahlah di Kabupaten Jember. Variabel independen yang diduga mempengaruhi kesediaan membayar responden beras cerdas CV An - Nahlah di Kabupaten Jember. Variabel independen yang diduga mempengaruhi kesediaan membayar adalah usia (X1), jenis kelamin (D1), status pernikahan (D2), pendidikan terakhir (X4), jenis pekerjaan (D3), pendapatan perbulan (X6) sedangkan variabel - variabel lain yang tidak dimasukkan dalam model persamaan dianggap konstan. Uji statistik yang digunakan adalah uji statistik $f$ dan uji statistik t. Hasil analisis menggunakan alat bantu SPSS 16 dapat dilihat pada tabel 10.

Berdasarkan tabel 10. dapat diketahui bahwa nilai adjusted $\mathrm{R}$ Square adalah 0,628 atau sebesar $62,8 \%$. Nilai tersebut memiliki arti bahwa sebesar $62,8 \%$ nilai WTP beras cerdas CV An - Nahlah dipengaruhi dan sudah dapat dijelaskan oleh variabel - variabel independen yang ada didalam model. Sedangkan sisanya $37,2 \%$ dipengaruhi oleh variabel - variabel lain yang berada diluar model.

Uji F bertujuan untuk mengetahui apakah semua variabel independen yang dimasukkan dalam model mempunyai pengaruh secara bersama - sama terhadap variabel dependen. Hasil uji $\mathrm{F}$ diketahui bahwa nilai signifikansi ANOVA yang diperoleh adalah $0,000<0,05$ dan F-hitung sebesar 11,992 > F-tabel sebesar 2,34 artinya variabel independen (usia, jenis kelamin, status pernikahan, pendidikan terakhir, jenis pekerjaan, dan pendapatan) berpengaruh secara nyata terhadap variabel dependen (WTP beras cerdas CV An - Nahlah). Sehingga dapat dikatakan bahwa model regresi yang digunakan sudah benar.

Variabel independen yang diduga menjadi faktor - faktor yang mempengaruhi keputusan responden dalam menentukan nilai WTP beras cerdas CV An - Nahlah adalah usia (X1), dummy jenis kelamin (D1), dummy status penikahan (D2), pendidikan terakhir (X4), dummy jenis pekerjaan (D3), dan pendapatan (X6). Hasil analisis tersebut dapat ditentukan dengan susunan dugaan model persamaan nilai WTP beras cerdas CV An - Nahlah sebagai berikut:

$\mathrm{WTP}=9338,543+675,400 \mathrm{X} 1-2257,257 \mathrm{D} 1$ $-42,450 \mathrm{D} 2+3008,846 \mathrm{X} 4-1541,862 \mathrm{D} 3+$ $1336,067 \mathrm{X} 6$

Penjabaran lebih detail mengenai hasil perhitungan uji regresi linier berganda atas faktor-faktor yang mempengaruhi nilai WTP beras cerdas CV An - Nahlah adalah sebagai berikut:

1. Variabel Usia (X1)

Variabel usia memiliki nilai koefisien regresi positif yaitu sebesar 675,400 , hal ini menunjukkan bahwa semakin tinggi tingkatan kelompok usia maka akan meningkatkan nilai WTP responden sebesar 675,400 rupiah. Variabel usia pada penelitian ini dibedakan menjadi beberapa kategori, yaitu dewasa awal (19-24thn), dewasa lanjut (25-35th), separuh baya (36-50th), dan tua (51-65th). Seiring dengan peningkatan kategori umur akan meningkatkan kesediaan membayar 
responden sebesar Rp 675 per 800 gram beras cerdas CV An - Nahlah. Nilai t hitung sebesar 2,049 > t tabel sebesar 2,032241, maka H0 ditolak artinya variabel usia berpengaruh secara nyata terhadap nilai WTP responden beras cerdas CV An - Nahlah. Nilai signifikansi t-hitung variabel usia sebesar $0,048<0,05$, artinya variabel usia berpengaruh secara nyata terhadap WTP responden beras cerdas CV An - Nahlah dengan tingkat kepercayaan $95 \%$.

2. Variabel Jenis kelamin $\left(D_{1}\right)$

Variabel jenis kelamin dalam penelitian ini dikategorikan menggunakan variabel dummy, dimana laki - laki bernilai 1 dan perempuan bernilai 0 . Variabel jenis kelamin memiliki nilai koefisien regresi negatif yang artinya responden laki - laki memiliki nilai WTP lebih rendah sebesar 2257,257 rupiah dibandingkan dengan responden perempuan. Nilai $t$ hitung sebesar $-2,470>\mathrm{t}$ tabel sebesar 2,03224, maka H0 ditolak artinya variabel jenis kelamin berpengaruh secara nyata terhadap WTP beras cerdas CV An - Nahlah. Nilai signifikansi variabel jenis kelamin adalah $0,019<0,05$ artinya variabel jenis kelamin berpengaruh secara nyata terhadap nilai WTP responden beras cerdas CV An - Nahlah dengan tingkat kepercayaan 95\%.

3. Variabel Status pernikahan $\left(D_{2}\right)$

Variabel status pernikahan dalam penelitian ini dikategorikan menggunakan variabel dummy, dimana responden yang belum menikah bernilai 1 dan responden yang sudah menikah bernilai 0 . Variabel status pernikahan memiliki nilai koefisien regresi negatif yang artinya responden yang belum menikah memiliki nilai WTP lebih rendah sebesar 42,450 rupiah dibandingkan dengan responden yang sudah menikah. Namun hal tersebut tidak terbukti secara statistik karena nilai t- hitung 0,041 $<$ t-tabel 2,03224, maka H0 diterima artinya variabel status pernikahan tidak berpengaruh secara nyata terhadap WTP beras cerdas. Nilai signifikansi $0,967>0,05$ artinya variabel status pernikahan tidak berpengaruh secara nyata terhadap WTP beras cerdas CV An - Nahlah pada tingkat kepercayaan $95 \%$.

5. Variabel Pendidikan terakhir $\left(\mathrm{X}_{4}\right)$

Variabel pendidikan memiliki nilai koefisien regresi positif sebesar 3008,846. Pendidikan terakhir dalam penelitian terdapat tiga tingkatan yaitu, SMP, SMA, S1/D3. Nilai koefisien regresi variabel pendidikan menunjukkan bahwa semakin tinggi tingkat pendidi- kan terakhir responden maka akan menaikkan nilai kesediaan membayar sebesar Rp 3.008 per 800 gram beras cerdas CV An - Nahlah. Nilai t-hitung sebesar 5,279 > t-tabel 2,03224, maka $\mathrm{H} 0$ ditolak artinya variabel pendidikan terakhir berpengaruh secara nyata terhadap WTP responden beras cerdas CV An - Nahlah. Hasil signifikansi t-hitung variabel pendidikan terkahir bernilai $0,102 \mathrm{E}^{-6}<0,05$ artinya variabel pendidikan terakhir berpengaruh secara nyata terhadap WTP responden beras cerdas CV An - Nahlah dengan tingkat kepercayaan $95 \%$.

6. Variabel Pekerjaan $\left(D_{3}\right)$

Variabel jenis pekerjaan dalam penelitian ini dikategorikan menggunakan variabel dummy, dimana non pegawai bernilai 1 dan pegawai bernilai 0. Variabel pekerjaan memiliki nilai koefisien regresi sebesar $-1541,862$. Nilai koefisien regresi variabel pekerjaan yang negatif berarti nilai kesediaan membayar non pegawai lebih rendah sebesar 1541,862 rupiah dibandingkan pegawai. Nilai t-hitung sebesar 2,217 > t-tabel sebesar 2,03224, maka H0 ditolak artinya variabel pekerjaan berpengaruh secara nyata terhadap WTP responden beras cerdas CV An - Nahlah.. Nilai signifikansi t-hitung variabel pekerjaan sebesar $0,034<0,05$ sehingga secara statistik variabel ini berpengaruh secara nyata terhadap WTP responden beras cerdas CV An Nahlah dengan tingkat kepercayaan 95\%.

7. Variabel Pendapatan per bulan $\left(\mathrm{X}_{6}\right)$

Variabel pendapatan memiliki nilai koefisien regresi sebesar 1336,067. Pada penelitian ini variabel pendapatan dikategorikan menjadi tiga yaitu : (1) $<$ Rp1.500.000, (2) $\mathrm{Rp} 1.500 .000$ - Rp 3.000.000, dan (3) $>$ Rp3.000.000. Nilai koefisien regresi variabel pendapatan positif, artinya setiap meningkatnya nilai kategori pendapatan akan menaikkan nilai kesediaan membayar sebesar Rp 1.336 per 800 gram beras cerdas CV An - Nahlah. Secara teoritis hal ini sesuai, karena menurut Suwarman (2015) semakin tinggi tingkat pendapatan konsumen, semakin tinggi pula memiliki daya belinya. Daya beli ini akan menggambarkan banyaknya produk dan jasa yang bisa dibeli dan dikonsumsi oleh seorang konsumen dan seluruh anggota keluarganya. Hal tersebut terbukti secara statistik karena nilai t-hitung sebesar 2,768 $>$ t tabel sebesar 2,03224, maka H0 ditolak artinya variabel pendapatan berpengaruh secara nyata terhadap WTP responden beras cerdas CV An - Nahlah. Nilai signifikansi adalah sebesar 
$0,009<0,05$ sehingga secara statistik variabel ini berpengaruh secara nyata terhadap WTP responden beras cerdas CV An - Nahlah dengan tingkat kepercayaan 95\%.

\section{KESIMPULAN}

Berdasarkan hasil penelitian yang dilakukan terhadap Kesediaan Membayar (Willingness to pay) Beras Cerdas CV An - Nahlah di Kabupaten Jember, maka dapat disimpulkan bahwa:

1. Karakteristik konsumen berkaitan dengan kesediaan membayar (willingness to pay), hasil penelitian ini menunjukkan bahwa responden berjenis kelamin perempuan, memiliki usia paruh baya, berstatus sudah menikah, memiliki pendidikan terakhir Sarjana atau Diploma, berstatus pegawai, dan berpenghasilan $\mathrm{Rp}$ 1.500.000 - Rp 3.000.000 memiliki jumlah kesediaan membayar terbanyak pada range harga Rp17.001 - Rp21.000 per 800 gram beras cerdas CV An - Nahlah.

2. Nilai rata-rata maksimum kesediaan membayar konsumen beras cerdas CV An-Nahlah di Kabupaten Jember adalah sebesar Rp 20.075 per 800 gram. Nilai ini lebih tinggi dibandingkan harga yang berlaku dipasar yaitu $\mathrm{Rp}$ 18.500 sehingga didapatkan surplus konsumen sebesar Rp 1.575. Permintaan konsumen terhadap beras cerdas CV An - Nahlah pada harga Rp 18.500 sebesar 87,5\% dan konsumen yang tidak dapat menjangkau sebesar $12,5 \%$, sedangkan permintaan konsumen pada harga Rp 20.075 sebesar 42,5\% dan konsumen yang tidak dapat menjangkau sebesar 57,5\%.

3. Faktor-faktor yang berpengaruh nyata terhadap kesediaan membayar beras cerdas $\mathrm{CV}$ An - Nahlah pada tingkat kepercayaan 95\% adalah usia, jenis kelamin, pendidikan terakhir, pekerjaan, dan pendapatan perbulan.

\section{DAFTAR PUSTAKA}

Foreit, K.G.F. dan J.R. Foreit. 2004. Willingness to Pay Surveys for Setting Price For Reproductive Health Product and Services, A User's Manual. The Project between with Population Council's Frontiers in Reproductive Health Program and International Devlopment. The Futures Group International Policy Project.

Ghozali, Imam. 2009. Ekonometrika Teori Konsep dan Aplikasi dengan SPSS 17. Sema- rang : Badan Penerbit Universitas Diponegoro.

Hariyati, Yuli. 2007. Ekonomi Mikro Pendekatan Matematis Dan Grafis. Jember : CSS.

Nazir, Mohamad.2011. Metode Penelitian. Bogor: Ghalia Indonesia.

Nitisusastro, Mulyadi. 2012. Perilaku Konsumen dalam Perspektif Keewairausahaan. Bandung : Alfabeta.

Setiadi, N J. 2010. Perilaku Konsumen Edisi Revisi. Bandung : Kencana Pendana Media Group.

Sugiyono. 2008. Metode Penelitian Kuantitatif dan Kualitatif dan R\&D. Bandung : Alfabeta Bandung.

Sumarni, Murti dan Salamah, Wahyuni. 2005. Metodologi Penelitian Bisnis. Yogyakarta : Andi Yogyakarta.

Sumarwan, Ujang. 2015. Perilaku Konsumen Teori dan Penerapannya dalam Pemasaran. Bogor : PT Ghalia Indonesia.

Suwanda, Aklima Dhiska. 2012. Analisis Kesediaan Membayar (Willingness To Pay) Beras Analog di Serambi Botani, Botani Square, Bogor. Diterbitkan. Skripsi. Bogor : Institut Pertanian Bogor. 